\title{
Mid-term results of tunneled brachial venous hemodialysis catheter placement: Our single-center experience with 21 patients
}

\author{
Tünelli brakiyal venöz hemodiyaliz kateter yerleştirmesinin orta dönem sonuçlarl: \\ 21 hasta ile tek merkezli deneyimimiz
}

\author{
Emced Khalil[ \\ Department of Cardiovascular Surgery, Ordu University Training and Research Hospital, Ordu, Turkey
}

\begin{abstract}
Background: This study aims to analyze the safety and efficacy of permanent hemodialysis catheter insertion via the brachial vein in unsuitable patients for catheter insertion from other vascular access sites.

Methods: A total of 21 patients (6 males, 18 females; mean age: $54.4 \pm 11.3$ years; range, 48 to 77 years) who underwent permanent hemodialysis catheter insertion via the brachial vein between February 2019 and February 2020 were retrospectively analyzed. All patients underwent brachial venous tunneled catheter insertion under the ultrasound guidance and under local anesthesia. Transthoracic echocardiography was performed before and six months after catheter insertion. The primary patency rate of the catheter at six months of follow-up, potential associated complications of a permanent hemodialysis catheter including catheter thrombosis and catheter infections, and all-cause mortality rates were recorded.
\end{abstract}

Results: Catheter removal was required in eight patients (catheter thrombosis, $\mathrm{n}=5$; catheter infection, $\mathrm{n}=2$; and extensive hematoma, $n=1)$. The catheters were patent in the remaining $13(62 \%)$ patients at six months. Mortality occurred in one patient due to bacterial pneumonia. No life-threatening complications including hemothorax or pneumothorax and neurological injury was observed in any of the patients.

Conclusion: Our study results show that brachial venous tunneled catheter placement for hemodialysis can be a safe and valid alternative to catheter insertion from the jugular or subclavian veins for vascular access in patients with end-stage renal disease.

Keywords: Brachial vein, catheter, hemodialysis, tunneled.

\section{$\ddot{O} Z$}

Amaç: Bu çalışmada diğer vasküler erişim bölgelerinden kateter yerleştirme işlemine uygun olmayan hastalarda brakiyel venden kalıcı hemodiyaliz kateter yerleştirilmesinin güvenliliği ve etkinliği değerlendirildi.

Çalışma planı: Şubat 2019-Şubat 2020 tarihleri arasında brakiyel venden kalıcı hemodiyaliz kateteri yerleştirilen toplam 21 hasta (6 erkek, 18 kadın; ort. yaş: $54.4 \pm 11.3$ yıl; dağılım, 48-77 yıl) retrospektif olarak incelendi. Hastaların tümüne ultrason eşliğinde ve lokal anestezi ile brakiyel venöz tünelli kateter yerleştirme işlemi yapıld1. Kateter yerleştirilmesinden önce ve altı ay sonra transtorasik ekokardiyografi çekildi. Takibin altıncı ayında kateterin primer açıklık oranı, kateter trombozu ve kateter enfeksiyonları gibi kalıcı hemodiyaliz kateteri ile ilişkili muhtemel komplikasyonlar ve tüm nedenlere bağlı mortalite oranları kaydedildi.

Bulgular: Sekiz hastada kateterin çıkarılması gerekti $(\mathrm{n}=5$ kateter trombozu, $\mathrm{n}=2$ kateter enfeksiyonu ve $\mathrm{n}=1$ büyük hematom). Altınc1 ayda geriye kalan 13 hastada (\%62) kateterler açıktı. Bir hastada bakteriyel pnömoniye bağlı mortalite izlendi. Hastaların hiçbirinde hemotoraks veya pnömonotoraks gibi yaşamı tehdit eden komplikasyonlar ve nörolojik hasar görülmedi.

Sonuç: Çalışma sonuçlarımız, hemodiyaliz için brakiyel venöz tünelli kateter yerleştirilmesinin, son dönem böbrek hastalığı olan hastalarda, juguler veya subklavyen venlerden yapılan kateter yerleştirilmesine güvenli ve geçerli bir alternatif olabileceğini göstermektedir.

Anahtar sözcükler: Brakiyel ven, kateter, hemodiyaliz, tünelli.

Received: June 27, 2020 Accepted: September 16, 2020 Published online: January 13, 2021

Correspondence: Emced Khalil, MD. Ordu Üniversitesi Eğitim ve Araştırma Hastanesi Kalp ve Damar Cerrahisi Kliniği, 52200 Altınordu, Ordu, Türkiye. Tel: +90 505 - 2401565 e-mail: emjedkhalil@gmail.com 
Increased life expectancy leads to an increase in the incidence of chronic renal failure, and thousands of patients with end-stage renal disease are scheduled for hemodialysis each year, which filtrates the blood and restores the body fluid and chemical homeostasis, particularly for those who are not candidates for renal transplantation. Creation of an effective and long-lasting vascular access site is, thus, crucial to provide hemodialysis.

External shunt and internal arteriovenous fistula (AVF) are the two most common vascular access methods. ${ }^{[1]}$ Creating an AVF to provide vascular access in hemodialysis patients has been shown to reduce morbidity and improve survival compared to catheters. ${ }^{[2]}$ However, initial AVF maturation is unsatisfactory in up to $60 \%$ of cases. ${ }^{[3]}$ Moreover, hemodialysis through an AVF is contraindicated in certain cases including those with reduced left ventricular ejection fraction (LVEF), life expectancy less than one year, poor vasculature, central vein occlusion, severe peripheral vascular disease and pacemaker line in access arm. ${ }^{[4]}$ Permanent catheter insertion for hemodialysis is a valid option for these patients who are not candidates for AVF creation. ${ }^{[5-7]}$ The jugular and subclavian veins are the most frequently used access sites for the insertion of a tunneled permanent hemodialysis catheter, but occasionally, the femoral vein is also utilized..$^{[8]}$ Nonetheless, the use of the aforementioned vascular access sites may be problematic in patients with advanced heart failure or morbid obesity, who are unable to stay in the Trendelenburg position during catheter insertion. Thus, the choice of vascular access site in these patients remains as a critical issue.

In the present study, we hypothesized that permanent catheter insertion from the brachial vein could be a valid alternative for vascular access among patients in whom catheter insertion from the jugular or subclavian veins were not feasible. We, therefore, aimed to analyze the safety and efficacy of permanent hemodialysis catheter insertion via the brachial vein in patients with contraindications for catheter insertion from other vascular access sites.

\section{PATIENTS AND METHODS}

A total of 21 patients ( 6 males, 18 females; mean age: $54.4 \pm 11.3$ years; range, 48 to 77 years) who underwent permanent hemodialysis catheter insertion via the brachial vein between February 2019 and February 2020 were retrospectively analyzed. Demographic characteristics and clinical features of the patients were retrieved from the institutional digital database. Inclusion criteria were as follows: the presence of New
York Heart Association (NYHA) Class III-IV systolic heart failure and life-threatening pulmonary edema, occluded femoral veins or history of femoral vein thrombosis, or morbidly obese patients with a body mass index of $<35 \mathrm{~kg} / \mathrm{m}^{2}$. Exclusion criteria were as follows: Subjects with a preexisting brachiocephalic or basilo-brachial AVF, occluded brachiocephalic AVF, left ventricular ejection fraction $>35 \%$, and those with a body mass index of $<22 \mathrm{~kg} / \mathrm{m}^{2}$. A written informed consent was obtained from each patient. The study protocol was approved by the Ordu University Faculty of Medicine Ethics Committee (Approval No: 2020/158). The study was conducted in accordance with the principles of the Declaration of Helsinki.

All patients underwent upper extremity venous ultrasound imaging to confirm the patency of the axillary and brachial veins. All procedures were carried out in an operation theatre under conscious sedation with intravenous midazolam $5 \mathrm{mg}$. Following the application of local anesthesia with prilocaine, a straight tip, double-lumen, $12.5 \mathrm{~F} \times 28-\mathrm{cm}$ cuffed catheters (CardioMed Supplies Inc., Ontario, Canada) was inserted from the left brachial vein (Figure 1). The cuffed catheter line position was confirmed via live fluoroscopy during insertion. The target point for the catheter tip was the high right atrium or aortocaval junction (Figure 2). The catheter position was modified under fluoroscopy to reach the target point. To diagnose possible complications, chest X-ray was performed in all patients after the procedure (Figure 3). All patients underwent transthoracic echocardiography before and two weeks after the procedure to measure LVEF and to identify the presence or absence of atrial thrombi. Hemodialysis nurses were trained to use central venous catheters (CVCs), and only trained nurses handled CVCs with sterile gloves and povidone-iodine disinfection.

Since it is closer to the right side, the right-side catheter insertion was the first choice for the patients $(n=19)$. The left-sided intervention was performed in only two patients, as the right axillary vein and right jugular vein were occluded in the first patient, and the second patient had a permanent pacemaker on the right side.

The primary catheter patency at six months, potential complications of permanent hemodialysis catheter including catheter thrombosis and catheter infections, and all-cause mortality rates were recorded.

\section{Statistical analysis}

Statistical analysis was performed using the IBM SPSS version 21.0 software (IBM Corp., 

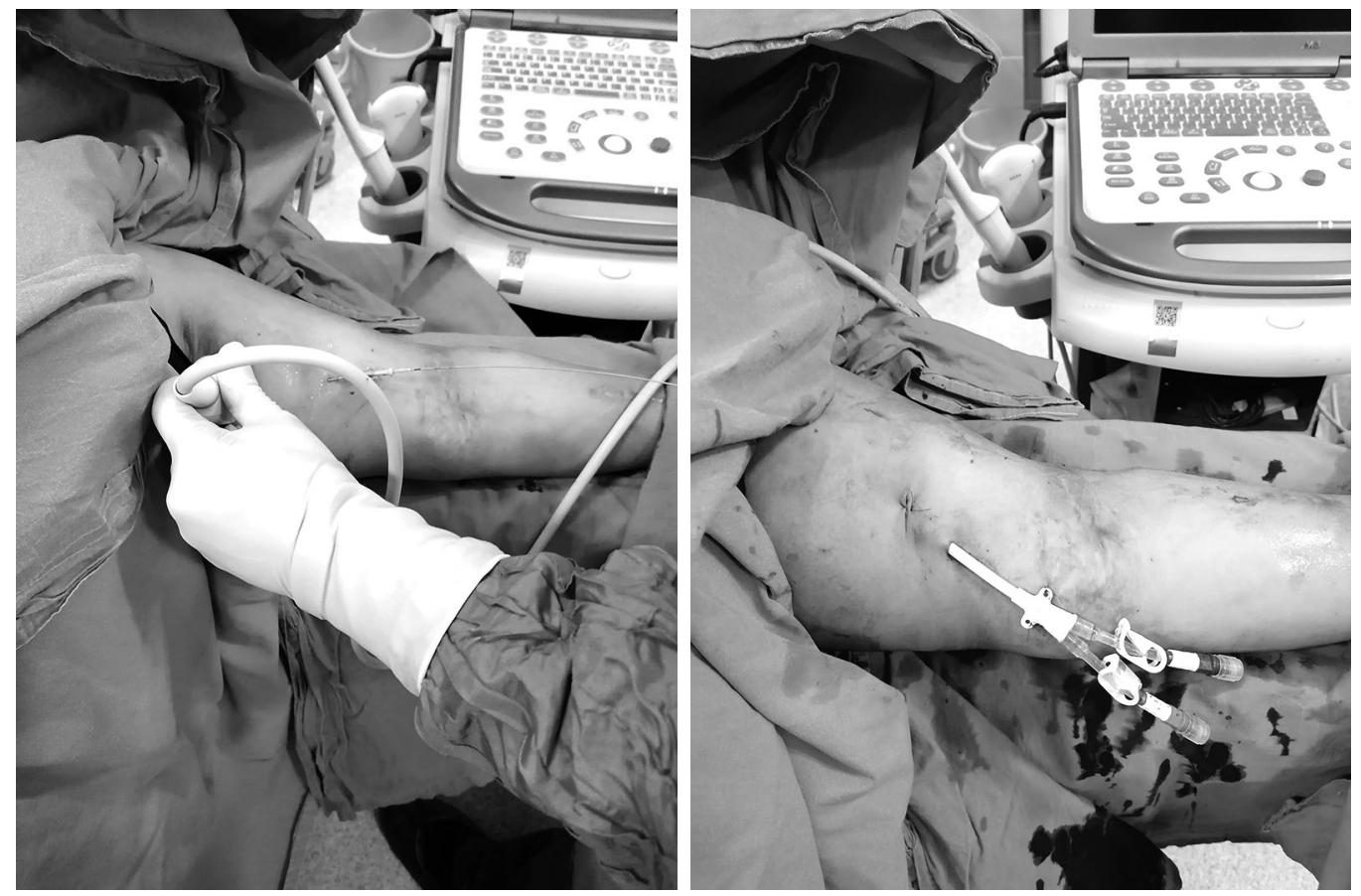

Figure 1. Permanent tunneled brachial venous hemodialysis catheter placement.
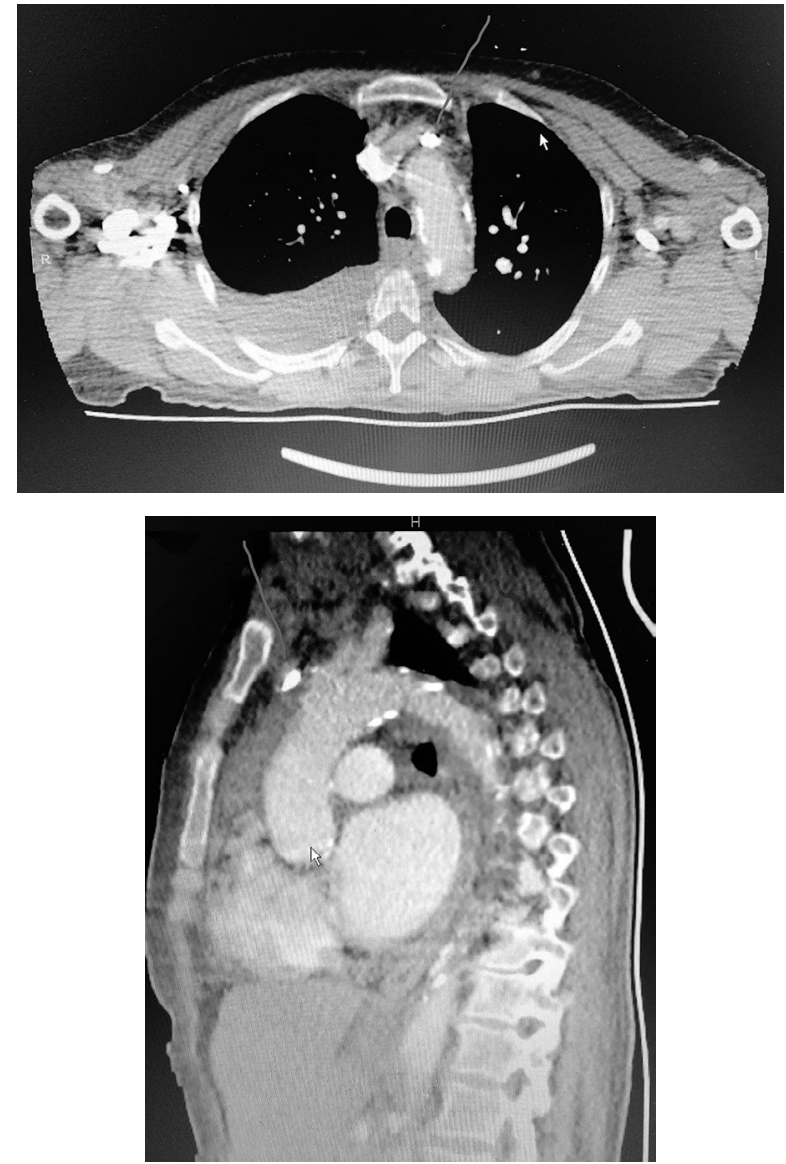

Figure 2. In CT, dialysis catheter tip seems to be very close to superior vena cava.

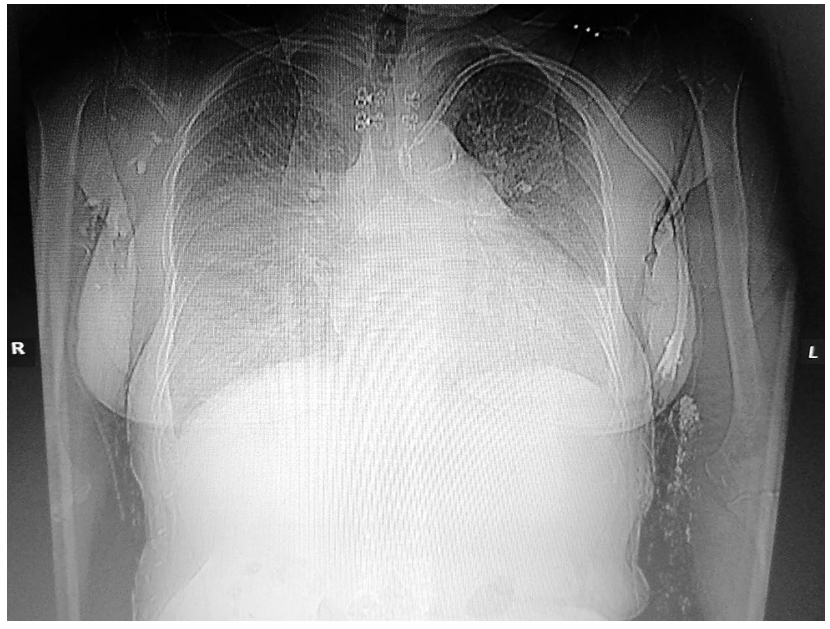

Figure 3. Control posterior anterior thoracic X-ray withdrawal showing that it reaches near the superior vena cava from the left axillary vein.

Armonk, NY, USA). The Shapiro-Wilk test was used to determine whether variables were normally distributed. Data were expressed in mean \pm standard deviation (SD) or median (min-max) for continuous variables, and in number and frequency for categorical variables. The paired samples t-test was performed to compare LVEF values at baseline and six months. A two-tailed $p$ value of $<0.05$ was considered statistically significant. 


\section{RESULTS}

The mean BMI was $31.4 \pm 3.1 \mathrm{~kg} / \mathrm{m}^{2}$ and the mean LVEF was $32.5 \pm 2.7 \%$ at baseline. Thirteen $(61.9 \%)$ patients were in NYHA Class III and eight (38.1\%) were in NYHA Class IV. Baseline demographic and clinical characteristics of the patients are presented in Table 1.

The mean follow-up was 6 (range, 2 to 9) months. The mean LVEF at six months was $30.6 \pm 3.3 \%$, indicating no significant difference compared to baseline $(\mathrm{p}=0.194)$. Catheter removal was required in eight patients (catheter thrombosis [ $n=5]$, catheter infection $[\mathrm{n}=2]$, and extensive hematoma $[n=1])$. The catheters were patent in the remaining

Table 1. Demographic features and clinical characteristics of patients

\begin{tabular}{lccc}
\hline & $\mathrm{n}$ & $\%$ & Mean $\pm \mathrm{SD}$ \\
\hline Age (year) & & & $54.4 \pm 11.3$ \\
Sex & 6 & 28.5 & \\
$\quad$ Male & & & $31.4 \pm 3.1$ \\
Body mass index $\left(\mathrm{kg} / \mathrm{m}^{2}\right)$ & & & \\
Comorbid disease & 9 & 42.8 & \\
$\quad$ Diabetes & 11 & 52.3 & \\
$\quad$ Hypertension & 12 & 57.1 & \\
$\quad$ Obesity & 7 & 33.3 & \\
$\quad$ Chronic obstructive & 5 & 23.8 & \\
$\quad$ pulmonary disease & & & \\
$\quad$ Smoking & & & \\
NYHA Class & 13 & 61.9 & \\
$\quad$ III & 8 & 38.1 & \\
$\quad$ IV & & & $32.5 \pm 2.7$ \\
Baseline left ventricular & & & \\
ejection fraction (\%) & &
\end{tabular}

SD: Standard deviation; NYHA: New York Heart Association.

Table 2. Outcomes of brachial venous tunneled catheter insertion at Month 6

\begin{tabular}{lccc}
\hline & $\mathrm{n}$ & $\%$ & Mean $\pm \mathrm{SD}$ \\
\hline Patency rate & 13 & 62 & \\
Catheter removal & & & \\
$\quad$ Catheter thrombosis & 5 & 23.8 & \\
$\quad$ Catheter infection, & 2 & 9.5 & \\
$\quad$ Hematoma & 1 & 4.7 & \\
Left ventricular ejection & & & $30.6 \pm 3.3$ \\
fraction (\%) & & & \\
\hline
\end{tabular}

SD: Standard deviation; NYHA: New York Heart Association.
13 (62\%) patients at six months of follow-up. Mortality occurred in one patient due to bacterial pneumonia. Life-threatening complications including hemothorax and pneumothorax, and neurological damage such as brachial plexus injury were not observed in any of the patients. None of the patients had ipsilateral arm edema or ischemia. In addition, median nerve injury, which can be encountered during brachial vein catheterization, was not observed in any of the patients. Outcomes of brachial venous tunneled catheter insertion at six months are shown in Table 2.

\section{DISCUSSION}

The number of patients requiring long-term hemodialysis is increasing in parallel with extended life-expectancy. ${ }^{[9,10]}$ Creating and maintaining a permanent vascular access is critical for effective hemodialysis in end-stage renal disease. The ideal vascular access for hemodialysis not only should provide adequate flow rate, but must have also long life and low vascular complication rate. ${ }^{[11]}$

In general, native AVFs, synthetic arteriovenous grafts fistulas, and tunneled CVCs are used for permanent vascular access. ${ }^{[12,13]}$ Among these vascular access options, native AVFs are unique, as they are well-known to have a considerably better flow rate and fewer vascular complications than the other methods. ${ }^{[12,14,15]}$ Moreover, native AVFs are safer and more reliable with lower morbidity and mortality than catheters. ${ }^{[16]}$ On the other hand, several reports have indicated that maturation of native AVF access may be unsatisfactory in up to $60 \%$ of the patients within the first six months. ${ }^{[17-19]}$ In addition, several clinical conditions, including reduced LVEF, having a life expectancy of less than one year, poor vasculature, central vein occlusion, severe peripheral vascular disease, and pacemaker line in the access side are reported as contraindications for the creation of native AVF access. ${ }^{[15]}$ Consequently, these patients are candidates for placement of a permanent tunneled hemodialysis catheter to maintain effective hemodialysis.

Although double-lumen CVCs were initially introduced for temporary use to maintain vascular access for an effective hemodialysis during the maturation of the native AVF, long-term use of these catheters inevitably became popular with the increasing number of patients who were unsuitable candidates for AVF creation. ${ }^{[20-22]}$ Previous data from the United States have shown that the number of permanent tunneled catheters has increased as a result 
of the increased quantity of diabetics and elderly patients with end-stage renal disease, in whom creating a native AVF is complicated in the presence of several comorbidities. ${ }^{[23]}$

Despite the limitations, placement of a permanent CVC to provide vascular access for long-term hemodialysis has several advantages, including multiple sites for catheter placement, no requirement for maturation, less hemodynamic change than native AVF, and reduced cost. ${ }^{[14]}$ There are studies demonstrating that permanent catheters can remain patent up to 18 months after insertion. ${ }^{[2]}$ Nonetheless, catheter thrombosis and infections which have been described to affect around $40 \%$ and $54 \%$ of patients, respectively are important concerns that limit the use of these types of catheters. ${ }^{[25,26]}$ Although CVCs are not the first choice in obtaining vascular access for hemodialysis at our institution, permanent central catheter insertion is reserved as an alternative where the other forms of access have failed or in cases where they cannot be performed.

Permanent tunneled catheters are preferably inserted into central veins. The internal jugular vein is the preferred insertion site for tunneled cuffed venous dialysis catheters. ${ }^{[27]}$ Alternatively, the right external jugular vein, left internal and external jugular veins, subclavian veins, femoral veins, and translumbar and transhepatic access to the inferior vena cava can be considered. ${ }^{[28]}$ However, catheter insertion from the internal jugular vein is performed in the Trendelenburg position and, therefore, may be complicated in patients with morbid obesity, advanced heart failure, and severe chronic obstructive pulmonary disease due to reduced alveolar volume and increased venous return in this position. In this study, we investigated whether a brachial tunneled catheter, which does not require Trendelenburg positioning, could provide a safe and effective vascular access in patients with dyspnea due to severe chronic obstructive pulmonary disease or heart failure. The primary patency rate of a tunneled, permanent catheter inserted from the internal jugular vein was reported as $67 \%$ at six months in a previous study. ${ }^{[29]}$ In this study, the primary patency rate of the brachial venous tunneled catheter at six months was $62 \%$, which is comparable to that of internal jugular vein catheters reported in previous studies. The reported six-month primary patency rates of the femoral vein tunneled catheters range between 32 and $67 \% .^{[30,31]}$ From this point of view, brachial venous tunneled catheter insertion appears to be superior to femoral venous catheter insertion in terms of six-month patency rate. In addition, the complication rates including catheter thrombosis and infection were $24 \%$ and $9 \%$, respectively. In a study conducted by Sepas et al., ${ }^{[32]}$ the thrombosis and infection rates of internal jugular vein permanent catheters were reported as $21 \%$ and $16 \%$, respectively. As such, brachial venous permanent catheter insertion seems to provide a similar safety in terms of catheter thrombosis and infection, compared to jugular venous catheter insertion. Moreover, brachial venous approach seems to be superior to the other vascular access sites in terms of reducing the rate of life-threatening complications, such as hemothorax or pneumothorax. Echocardiography findings also revealed that there were no adverse effects in the cardiovascular system at six months of follow-up after brachial permanent catheter insertion, and the LVEF of the patients remained stable.

The CVC insertion is routinely performed under the guidance of ultrasonography (USG) in our institute. However, despite the USG guidance, tunneled catheter insertion may be problematic in these patients. One of the main objectives of this study was to assess whether brachial venous catheter insertion could be an alternative to catheter insertion form the jugular vein We, therefore, used the brachial vein as the access site for a tunneled hemodialysis catheter placement. The fact that we only performed follow-up evaluation at six months and were unable to evaluate the characteristics of patients at shorter intervals and in the longer term are probably the most important limitations. Additionally, the number of patients is relatively low to draw reliable conclusions concerning the frequency of complications. Nevertheless, we believe these results are valuable to demonstrate an option for a safe vascular access in patients who are suitable for neither AVF nor the usual catheter sites. Using brachial vein as the access site for tunneled hemodialysis catheter insertion is a new technique and our findings are the first preliminary data regarding its clinical use.

In conclusion, our study findings show that brachial venous tunneled catheter placement for hemodialysis can be a valid alternative to catheter insertion from the jugular or subclavian vein for vascular access in patients with end-stage renal disease. This technique seems to be safe in terms of life-threatening complications, such as hemothorax and pneumothorax with no significant adverse effects on the left ventricle at six months of follow-up. However, further large-scale, long-term, prospective 
studies are warranted to confirm these findings.

\section{Declaration of conflicting interests}

The author declared no conflicts of interest with respect to the authorship and/or publication of this article.

\section{Funding}

The author received no financial support for the research and/or authorship of this article.

\section{REFERENCES}

1. DeVita MV, Khine SK, Shivarov H. Novel approaches to arteriovenous access creation, maturation, suitability, and durability for dialysis. Kidney Int Rep 2020;5:769-78.

2. Lacson E Jr, Lazarus JM, Himmelfarb J, Ikizler TA, Hakim RM. Balancing fistula first with catheters last. Am J Kidney Dis 2007;50:379-95.

3. Biuckians A, Scott EC, Meier GH, Panneton JM, Glickman MH. The natural history of autologous fistulas as first-time dialysis access in the KDOQI era. J Vasc Surg 2008;47:415-21.

4. Dumaine C, Kiaii M, Miller L, Moist L, Oliver MJ, Lok CE, et al. Vascular access practice patterns in canada: A national survey. Can J Kidney Health Dis 2018;5:2054358118759675.

5. Raji YR, Ajayi SO, Aminu O, Abiola B, Efuntoye O, Salako $\mathrm{BL}$, et al. Outcomes of tunneled internal jugular venous catheters for chronic haemodialysis at the University College Hospital, Ibadan, Nigeria. Pan Afr Med J 2018;31:218.

6. Pašara V, Maksimović B, Gunjača M, Mihovilović K, Lončar A, Kudumija B, et al. Tunnelled haemodialysis catheter and haemodialysis outcomes: a retrospective cohort study in Zagreb, Croatia. BMJ Open 2016;6:e009757.

7. Özbudak E, Eraldemir FC, Arıkan AA, Şahin D, Maral Kir H, Kurt T, et al. An evaluation of rivaroxaban and clopidogrel in a rat lower extremity ischemia-reperfusion model: An experimental study. Turk Gogus Kalp Dama 2019;27:513-20.

8. Santoro D, Benedetto F, Mondello P, Pipitò N, Barillà D, Spinelli F, et al. Vascular access for hemodialysis: current perspectives. Int J Nephrol Renovasc Dis 2014;7:281-94.

9. Wanner C, Ketteler M. Chronic kidney disease. Dtsch Med Wochenschr 2017;142:193-6.

10. Webster AC, Nagler EV, Morton RL, Masson P. Chronic kidney disease. Lancet 2017;389:1238-52.

11. Robinson BM, Akizawa T, Jager KJ, Kerr PG, Saran R, Pisoni RL. Factors affecting outcomes in patients reaching end-stage kidney disease worldwide: differences in access to renal replacement therapy, modality use, and haemodialysis practices. Lancet 2016;388:294-306.

12. Coentrão L, Van Biesen W, Nistor I, Tordoir J, Gallieni M, Marti Monros A, et al. Preferred haemodialysis vascular access for diabetic chronic kidney disease patients: A systematic literature review. J Vasc Access 2015;16:259-64.

13. Thalhammer C, Segerer S. Hemodialysis vascular access. Dtsch Med Wochenschr 2014;139:1562-4.

14. Hayashi R, Huang E, Nissenson AR. Vascular access for hemodialysis. Nat Clin Pract Nephrol 2006;2:504-13.
15. Dumaine CS, Brown RS, MacRae JM, Oliver MJ, Ravani P, Quinn RR. Central venous catheters for chronic hemodialysis: Is "last choice" never the "right choice"? Semin Dial 2018;31:3-10.

16. Roca-Tey R. Permanent arteriovenous fistula or catheter dialysis for heart failure patients. J Vasc Access 2016;17 Suppl 1:S23-9.

17. Bashar K, Conlon PJ, Kheirelseid EA, Aherne T, Walsh SR, Leahy A. Arteriovenous fistula in dialysis patients: Factors implicated in early and late AVF maturation failure. Surgeon 2016;14:294-300.

18. Remuzzi A, Bozzetto M. Biological and physical factors involved in the maturation of arteriovenous fistula for hemodialysis. Cardiovasc Eng Technol 2017;8:273-9.

19. Siddiqui MA, Ashraff S, Carline T. Maturation of arteriovenous fistula: Analysis of key factors. Kidney Res Clin Pract 2017;36:318-28.

20. Agarwal AK, Haddad N, Boubes K. Avoiding problems in tunneled dialysis catheter placement. Semin Dial 2019;32:535-40.

21. Beecham GB, Aeddula NR. Dialysis Catheter. StatPearls. Treasure Island (FL): StatPearls Publishing Copyright ${ }^{\oplus} 2020$, StatPearls Publishing LLC.; 2020.

22. Gallieni M, Brenna I, Brunini F, Mezzina N, Pasho S, Giordano A. Dialysis central venous catheter types and performance. J Vasc Access 2014;15 Suppl 7:S140-6.

23. Rose DA, Sonaike E, Hughes K. Hemodialysis access. Surg Clin North Am 2013;93:997-1012.

24. Hind D, Calvert N, McWilliams R, Davidson A, Paisley S, Beverley $\mathrm{C}$, et al. Ultrasonic locating devices for central venous cannulation: meta-analysis. BMJ 2003;327:361.

25. Canaud B, Leray-Moragues H, Kerkeni N, Bosc JY, Martin K. Effective flow performances and dialysis doses delivered with permanent catheters: a 24-month comparative study of permanent catheters versus arteriovenous vascular accesses. Nephrol Dial Transplant 2002;17:1286-92.

26. Desjardins B, Rybicki FJ, Kim HS, Fan CM, Flamm SD, Gerhard-Herman MD, et al. ACR Appropriateness Criteria ${ }^{\circledR}$ Suspected upper extremity deep vein thrombosis. J Am Coll Radiol 2012;9:613-9.

27. Haddad NJ, Winoto J, Shidham G, Agarwal AK. Hemodialysis access monitoring and surveillance, how and why? Front Biosci (Elite Ed) 2012;4:2396-401.

28. Initiative NKFKDOQ. Clinical practice guidelines for 2006 updates: hemodialysis adequacy, peritoneal dialysis adequacy, and vascular access. Am J Kidney Dis 2006;48:S1-S322.

29. Maya ID, Allon M. Outcomes of tunneled femoral hemodialysis catheters: comparison with internal jugular vein catheters. Kidney Int 2005;68:2886-9.

30. Burton KR, Guo LL, Tan KT, Simons ME, Sniderman KW, Kachura JR, et al. Patency of femoral tunneled hemodialysis catheters and factors predictive of patency failure. Cardiovasc Intervent Radiol 2012;35:1396-402. 
Khalil.

Mid-term results of tunneled brachial venous hemodialysis catheter placement

31. Bertoli SV, Ciurlino D, Musetti C, Mazzullo T, Villa M, Traversi L, et al. Experience of 70-cm-long femoral tunnelled twin Tesio catheters for chronic haemodialysis. Nephrol Dial Transplant 2010;25:1584-8.
32. Sepas HN, Negahi A, Mousavie SH, Vosough F, Farazmand B. Patency and outcomes of tunneled hemodialysis catheter via femoral versus jugular vein access. J Adv Pharm Technol Res 2019;10:81-4. 